\title{
Correction to: Large-scale dynamics have greater role than thermodynamics in driving precipitation extremes over India
}

\author{
Naveen Sudharsan ${ }^{1} \cdot$ Subhankar Karmakar ${ }^{1,2,3} \cdot$ Hayley J. Fowler ${ }^{4} \cdot$ Vittal Hari $^{5}$ D
}

Published online: 2 August 2021

(c) The Author(s) 2021

\section{Correction to: Climate Dynamics (2020) 55:2603-2614 https://doi.org/10.1007/s00382-020-05410-3}

The article "Large-scale dynamics have greater role than thermodynamics in driving precipitation extremes over India", written by Naveen Sudharsan, Subhankar Karmakar, Hayley J. Fowler, Vittal Hari was originally published Online First without Open Access. After publication in volume 55, issue 9-10, page 2603-2614 the author decided to opt for Open Choice and to make the article an Open Access publication.

Therefore, the copyright of the article has been changed to (c) The Author(s) 2021 and the article is forthwith distributed under the terms of the Creative Commons Attribution 4.0 International License, which permits use, sharing, adaptation, distribution and reproduction in any medium or format, as long as you give appropriate credit to the original author(s) and the source, provide a link to the Creative Commons licence, and indicate if changes were made. The images or other third party material in this article are included in the article's Creative Commons licence, unless indicated otherwise in a credit line to the material. If material is not included in the article's Creative Commons licence

The original article can be found online at https://doi.org/10.1007/ s00382-020-05410-3.

\section{Vittal Hari}

vittal.hari@ufz.de

1 Environmental Science and Engineering Department, Indian Institute of Technology Bombay, Mumbai 400076, India

2 Interdisciplinary Program in Climate Studies, Indian Institute of Technology Bombay, Mumbai 400076, India

3 Centre for Urban Science and Engineering, Indian Institute of Technology Bombay, Mumbai 400076, India

4 School of Engineering, Newcastle University, Newcastle-upon-Tyne, UK

5 Department of Computational Hydrosystems, Helmholtz Centre for Environmental Research, UFZ, Leipzig, Germany and your intended use is not permitted by statutory regulation or exceeds the permitted use, you will need to obtain permission directly from the copyright holder. To view a copy of this licence, visit http://creativecommons.org/licen ses/by/4.0. Open access funding enabled and organized by Projekt DEAL.

The original article was corrected.

Publisher's Note Springer Nature remains neutral with regard to jurisdictional claims in published maps and institutional affiliations. 